\title{
Chemical Safety of Unpolished Nigerian Rice
}

\section{Akinsola Francis Awopetu, Joseph Adewuyi Adeyemi*, Oluwatosin Christianah Falope, Chris Olukayode Adedire}

Department of Biology, School of Sciences, Federal University of Technology, P.M.B. 704, Akure, Ondo State, Nigeria

\section{A R T I C L E I N F O}

\section{Research Article}

Received 17 September 2016 Accepted 13 February 2017

Keywords:

Food analysis

Rice consumption

Estimated daily intake

Essential elements

Toxic elements

*Corresponding Author:

E-mail: joseph.adeyemi@gmail.com

\section{A B S T R A C T}

Levels of arsenic (As), lead $(\mathrm{Pb})$, cadmium $(\mathrm{Cd})$, calcium $(\mathrm{Ca})$, chromium $(\mathrm{Cr})$, potassium $(\mathrm{K})$, sodium $(\mathrm{Na})$, and zinc $(\mathrm{Zn})$ in locally cultivated rice consumed in Ondo and Ekiti States of Nigeria were investigated. The rice samples were obtained from six different rice-producing towns; Akure, Ondo, Ado, Igbemo, Ikole and Erinjiyan. The estimated dietary intake (EDI) of these elements were determined and compared with the provisional tolerable daily intake (PTDI) and dietary reference intake (DRI) values for toxic and essential elements respectively. The measured mean levels of $\mathrm{Pb}, \mathrm{As}, \mathrm{Cr}, \mathrm{Cd}$, $\mathrm{Zn}, \mathrm{Na}, \mathrm{Ca}$ and $\mathrm{K}$ were $0.047 \pm 0.007,0.041 \pm 0.004,0.570 \pm 0.032,0.026 \pm 0.003,7.856$ $\pm 0.659,42.15 \pm 0.191,337.11 \pm 0.315$, and $2650.09 \pm 0.337 \mu \mathrm{g} / \mathrm{g}$ respectively while the average EDI were $00.101 \pm 0.042 \mu \mathrm{g} / \mathrm{day}, 0.088 \pm 0.14 \mu \mathrm{g} / \mathrm{day}, 1.234 \pm 0.045 \mu \mathrm{g} / \mathrm{day}$, $0.057 \pm 0.002 \mu \mathrm{g} / \mathrm{day}, 0.017 \pm 0.071 \mathrm{mg} / \mathrm{day}, 0.091 \pm 0.013 \mathrm{mg} / \mathrm{day}, 0.73 \pm 0.018 \mathrm{mg} / \mathrm{day}$ and $5.742 \pm 0.337 \mathrm{mg} /$ day respectively. The EDIs were not significantly higher than the reference values for the elements except $\mathrm{Cr}$. Also the rice samples were not rich enough in sodium, calcium and potassium compared to the dietary reference intakes for these elements. It is recommended that rice diets should be supplemented with other food items such as meat, fruits and vegetables.

\section{Introduction}

Rice is a staple cereal grain that is widely consumed all over the world, especially in Asia where it accounts for 35 to $60 \%$ of the calories consumed per day (Khush, 1997). Globally, rice consumption supplies 2,400 calories per person per day (FAO, 2000). In Nigeria, there have been great improvement in local rice production; from 207,200 tonnes/ha in 1961-1965 to 3,000,000 tonnes/ha in 1996-2000 (Ajijola et al., 2012). This is in response to increase in rice consumption in Nigeria and other African nations (Bamidele et al., 2010). Two types of rice are mainly cultivated in Nigeria: the African rice (Oryza glaberrima) and the Asian rice (Oryza sativa). Recently, new varieties of rice have been introduced e.g. NERICA (New Rice for Africa), which is an interspecific hybrid between the African and Asian rice.

The pollution of environment by heavy metals is of significant concern due to the reported adverse effects of metal pollution on human and other living organisms (Yoon, 2003). The dietary exposure of humans to toxic metals has elicited various adverse effects such as developmental retardation, several types of diseases such as cancer, kidney damage, endocrine disruption, immunological, neurological effects and other metabolic and physiological disorders (Mudgal et al., 2010). There have been reports that crops grown on soils contaminated with heavy metals have the potential to bioaccumulate those metals, and could be harmful to humans when such crops are consumed (Satpathy et al., 2014; Balkhair and Ashraf, 2016). Also, incidences of toxic elements in food items have been widely reported certain (Arsian and Arikan, 2013; Kurnaz et al., 2016; Ossai et al., 2016; Yilmaz et al., 2016).

The specific objectives of the study are two folds: firstly to determine the levels of some toxic and essential elements in locally cultivated rice samples consumed in different towns in both Ondo and Ekiti states of Nigeria, and secondly to estimate the dietary daily intake of the elements and compared to recommended daily intakes.

\section{Materials and Methods}

\section{Study Location and Sample Collection}

This study was carried out in Ondo and Ekiti states of Nigeria comprising different towns from each state. In Ondo state, the towns chosen were Akure and Ondo while Ado-Ekiti, Igbemo, Ikole-Ekiti, and Erinjiyan were chosen in Ekiti state. Both Ondo $\left(7^{\circ} 10^{\prime} \mathrm{N}, 5^{\circ} 05^{\prime} \mathrm{E}\right)$ and Ekiti $\left(7^{\circ} 40^{\prime} \mathrm{N}, 5^{\circ} 15^{\prime} \mathrm{E}\right)$ states are located in the SouthWestern part of Nigeria. The States are geographically within the rainforest zone of Nigeria and have marked wet and dry seasons (Iloeje, 2001). 
Rice samples were obtained at different points from the major markets (in the sampled towns), and were stored in polythene bags with proper identification. In the laboratory, the samples were sorted to eliminate stones, chaff, sticks and other unwanted materials. The samples were then pulverized in a mortar into fine, powdery forms. The pulverized samples were sieved to obtain very fine particles using a sieve of $0.5 \mathrm{~mm}$ mesh size.

\section{Sample Preparation and Metal Analyses}

Sample preparation and metal analyses followed standard procedures (APHA and WCPF, 1998; AOAC, 2003). Briefly, five (5) $\mathrm{g}$ each of the samples were transferred into digestion flasks after which $4 \mathrm{ml}$ of perchloric acid and $8 \mathrm{ml}$ of nitric acid were added. The digestion flasks were placed on a hot plate set at $120^{\circ} \mathrm{C}$ (gradually increased) until the samples were digested. The digested samples were diluted with distilled water appropriately in the range of standards which were prepared from stock standard solution of the metals. The determination of levels of $\mathrm{Cd}, \mathrm{Cr}, \mathrm{Pb}, \mathrm{As}$ and $\mathrm{Zn}$ in digested samples were performed using atomic absorption spectrophotometry (Model 210 VGP) while the levels of $\mathrm{Na}, \mathrm{K}$ and $\mathrm{Ca}$ were determined using flame photometry.

Estimation of Elemental Dietary Intake through Rice Consumption

The daily intake of elements depends on both the concentration in food and the daily food consumption. The EDIs of toxic and essential elements $(\mathrm{Pb}, \mathrm{As}, \mathrm{Cd}, \mathrm{Cr}$, $\mathrm{Zn}, \mathrm{Na}, \mathrm{Ca}$ and $\mathrm{K}$ ) were calculated as reported by Batista et al. (2011) and Adedire et al. (2015) as follows:

$$
\mathrm{EDI}=\mathrm{C}_{\mathrm{m}} \mathrm{X} \mathrm{\textrm {M } _ { \mathrm { g } }}
$$

where EDI is the estimated daily intake ( $\mathrm{mg} /$ day/individual or $\mu \mathrm{g} /$ day/individual), $\mathrm{C}_{\mathrm{m}}$ is the mean concentration of metals in the rice samples $(\mu \mathrm{g} / \mathrm{g}$ or $\mathrm{mg} / \mathrm{kg}$ ) and $\mathrm{M}_{\mathrm{g}}$ is the mass of rice consumed daily by an individual. The daily consumption of rice was taken as 70 g/day based on the report of The African Rice Center (2005) regarding rice consumption in Nigeria. The EDIs of the essential elements were compared to the dietary reference intakes (DRIs) obtained from the Food and Nutrition Board of the Institute of Medicine (2004). The EDI of the lead was compared with the European Food Safety Authority (EFSA, 2010) benchmark dose lower confidence limit, while the EDI of cadmium was compared to the provisional tolerable daily intake (PTDI) value obtained from provisional tolerable weekly intake (PTWI) values based on WHO guidelines.

\section{Data Analyses}

Data were reported as mean \pm standard deviation. The data on levels of metals were analyzed using a one-way analysis of variance. This was followed by Tukey's comparison tests whenever significant difference existed. All statistics were performed using SPSS 21.0 software (SPSS, Inc. 2013) and statistical significance was assumed at $\mathrm{P} \leq 0.05$.

\section{Results and Discussion}

Levels and Dietary Intakes of Toxic Elements in Rice Samples

The mean levels of toxic elements (arsenic, cadmium and lead) in rice samples from each location are shown in Table 1. The mean levels of the toxic elements differed significantly $(\mathrm{P}<0.05)$ in samples collected from different locations. The mean level of arsenic was highest in samples collected from Igbemo $(0.059 \pm 0.006 \mu \mathrm{g} / \mathrm{g})$ and lowest in samples obtained from Akure $(0.026 \pm 0.002$ $\mu \mathrm{g} / \mathrm{g})$. The detected mean level of arsenic in rice samples was just $8.2 \%$ of the upper limit of $0.5 \mu \mathrm{g} / \mathrm{g}$ allowed in food, and much lower than the reported levels of arsenic in rice samples from Brazil, Taiwan and Thailand which were found to be $0.223 \mu \mathrm{g} / \mathrm{g}, 0.383 \mu \mathrm{g} / \mathrm{g}$ and $0.11 \mu \mathrm{g} / \mathrm{g}$ respectively (Williams et al., 2005; Batista et al., 2011). The mean level of cadmium was highest in samples collected from Ikole-Ekiti $(0.038 \pm 0.005 \mu \mathrm{g} / \mathrm{g})$ and lowest in samples obtained from Ado-Ekiti $(0.015 \pm 0.003$ $\mu \mathrm{g} / \mathrm{g})$. The detected mean level of cadmium in rice samples was $6.5 \%$ of the upper limit of $0.4 \mu \mathrm{g} / \mathrm{g}$ allowed in food. The mean value of cadmium in these samples was higher than the value detected in Brazilian rice samples $(0.0127 \mu \mathrm{g} / \mathrm{g})$ but quite similar to the levels detected in South Korean and Swedish samples where cadmium levels were found to be 0.021 and $0.024 \mu \mathrm{g} / \mathrm{g}$ respectively (Fu et al., 2008; Jorhem et al., 2008; Batista et al., 2010). The mean level of lead in rice samples ranged from $0.051 \pm 0.007 \mu \mathrm{g} / \mathrm{g}$ in samples collected from Erinjiyan to $0.041 \pm 0.007 \mu \mathrm{g} / \mathrm{g}$ in samples obtained from Ado-Ekiti. The detected mean level of lead in rice samples was $23.5 \%$ of the upper limit of $0.2 \mu \mathrm{g} / \mathrm{g}$ permitted in food. The mean detected lead levels in this study were higher than the levels found in Chinese rice $(0.028 \pm 5.6 \mu \mathrm{g} / \mathrm{g}$; Fu et al., 2012) but similar to the detected level in Brazilian rice with a mean level of 0.057 $\mu \mathrm{g} / \mathrm{g}$ (Poletti et al., 2014). The observed high levels of toxic elements ( $\mathrm{As}, \mathrm{Pb}, \mathrm{Cd}$ ) in this study could be due to heavy soil pollution arising from indiscriminate waste disposal system, vehicular pollution and contamination with petroleum products (Huang et al., 2006).

Arsenic, cadmium and lead are extremely toxic to vertebrates including man. Arsenic is a human carcinogen; chronic exposure to arsenic has been shown to result in increased incidences of cancer in various body parts including buccal cavity, pharynx, lung etc. (Enterline et al., 1995). Human acute exposure to lead has been shown to cause encephalopathy, nausea and vomiting, and long term exposure resulted in nephropathy (kidney disease) and disruption of heam biosynthesis (Vavas-Acien et al., 2007). Cadmium has been reported to be nephrotoxic to human, causing renal dysfunction (Rastogi, 2008). The results of this study did not indicate any potential health hazard by toxic elements from consumption of local rice. The mean estimated daily intakes of arsenic, cadmium and lead were 2.87, 1.82 and $3.29 \mu \mathrm{g} /$ day for arsenic, cadmium and lead respectively, which are just $1.91,2.6$, and $9.4 \%$ of the provisional tolerable daily intake values for arsenic, cadmium and lead respectively (Table 3 ). 
Table 1 The levels of toxic elements in rice samples in Ondo and Ekiti states

\begin{tabular}{l|ccc}
\hline \multicolumn{1}{c|}{ Location } & Lead $(\mu \mathrm{g} / \mathrm{g})$ & Arsenic $(\mu \mathrm{g} / \mathrm{g})$ & Cadmium $(\mu \mathrm{g} / \mathrm{g})$ \\
\hline Akure & $0.044^{\mathrm{ab}} \pm 0.003$ & $0.026^{\mathrm{a}} \pm 0.002$ & $0.02^{\mathrm{ab}} \pm 0.006$ \\
Ondo & $0.048^{\mathrm{ab}} \pm 0.05$ & $0.031^{\mathrm{a}} \pm 0.003$ & $0.017^{\mathrm{a}} \pm 0.002$ \\
Ado-Ekiti & $0.041^{\mathrm{a}} \pm 0.007$ & $0.043^{\mathrm{bc}} \pm 0.004$ & $0.015^{\mathrm{a}} \pm 0.003$ \\
Igbemo & $0.049^{\mathrm{ab}} \pm 0.002$ & $0.059^{\mathrm{d}} \pm 0.006$ & $0.026^{\mathrm{b}} \pm 0.003$ \\
Ikole & $0.047^{\mathrm{ab}} \pm 0.002$ & $0.036^{\mathrm{ab}} \pm 0.011$ & $0.038^{\mathrm{c}} \pm 0.005$ \\
Erinjiyan & $0.051^{\mathrm{b}} \pm 0.007$ & $0.048^{\mathrm{c}} \pm 0.003$ & $0.042^{\mathrm{c}} \pm 0.002$ \\
Average conc. & $0.047 \pm 0.007$ & $0.041 \pm 0.004$ & $0.026 \pm 0.003$ \\
UL & $0.2^{*}$ & $0.5^{*}$ & $0.4^{*}$ \\
\hline
\end{tabular}

Each value is the mean \pm standard deviation of the six replicates. Means within the same column followed by the same letter (in superscript) are not significantly different but means with different letters are significantly different from others at P $>0.05$ using Tukey's test, * $=$ Tolerable Upper Intake Levels (UL) according to Food and Nutrition Board, Institute of Medicine, National Academies, 2004.

Table 2 The levels of essential elements in rice samples in Ondo and Ekiti states

\begin{tabular}{l|ccccc}
\hline \multicolumn{1}{c|}{ Location } & Sodium $(\mu \mathrm{g} / \mathrm{g})$ & Calcium $(\mu \mathrm{g} / \mathrm{g})$ & Chromium $(\mu \mathrm{g} / \mathrm{g})$ & Zinc $(\mu \mathrm{g} / \mathrm{g})$ & Potassium $(\mu \mathrm{g} / \mathrm{g})$ \\
\hline Akure & $39.37^{\mathrm{ab}} \pm 0.198$ & $330.58^{\mathrm{a}} \pm 0.699$ & $0.227^{\mathrm{a}} \pm 0.022$ & $6.833^{\mathrm{ab}} \pm 0.619$ & $2610.8^{\mathrm{a}} \pm 0.375$ \\
Ondo & $48.13^{\mathrm{d}} \pm 0.053$ & $343.6^{\mathrm{c}} \pm 0.270$ & $0.308^{\mathrm{b}} \pm 0.033$ & $6.067^{\mathrm{a}} \pm 0.628$ & $2625.8^{\mathrm{b}} \pm 0.145$ \\
Ado-Ekiti & $38.03^{\mathrm{a}} \pm 0.068$ & $337.73^{\mathrm{bc}} \pm 0.182$ & $0.648^{\mathrm{c}} \pm 0.028$ & $6.883^{\mathrm{a}} \pm 0.578$ & $2642.7^{\mathrm{c}} \pm 0.595$ \\
Igbemo & $43.0^{\mathrm{bc}} \pm 0.391$ & $329.92^{\mathrm{a}} \pm 0.043$ & $0.823^{\mathrm{e}} \pm 0.033$ & $8.9^{\mathrm{c}} \pm 0.754$ & $2662.5^{\mathrm{d}} \pm 0.588$ \\
Ikole-Ekiti & $44.82^{\mathrm{cd}} \pm 0.408$ & $344.17^{\mathrm{c}} \pm 0.227$ & $0.715^{\mathrm{d}} \pm 0.035$ & $9.933^{\mathrm{c}} \pm 1.663$ & $2686.8^{\mathrm{f}} \pm 0.068$ \\
Erinjiyan & $39.52^{\mathrm{ab}} \pm 0.026$ & $336.65^{\mathrm{ab}} \pm 0.473$ & $0.697^{\mathrm{cd}} \pm 0.043$ & $8.517^{\mathrm{bc}} \pm 1.102$ & $2671.9^{\mathrm{e}} \pm 0.255$ \\
Average conc. & $42.15 \pm 0.191$ & $337.11 \pm 0.315$ & $0.570 \pm 0.032$ & $7.856 \pm 0.659$ & $2650.1 \pm 0.337$ \\
UL & $2300^{*}$ & $2500^{*}$ & $N^{*} *$ & $40^{*} *$ & ND $^{*}$ \\
\hline
\end{tabular}

Each value is the mean \pm standard deviation of the six replicates. Means within the same column followed by the same letter (in superscript) are not significantly different but significantly different from others at $\mathrm{P}>0.05$ using Tukey's test, UL= Tolerable Upper Intake Levels, ND $=$ Not Determinable, *= Tolerable Upper Intake Levels (UL) according to Food and Nutrition Board, Institute of Medicine, National Academies, 2004.

Table 3 Estimated Daily Intake (EDI) ( $\mu \mathrm{g} /$ day or $\mathrm{mg} /$ day) of toxic metals, essential micronutrients and macronutrients compared to provisional tolerable daily intake (PTDI) for toxic elements and the dietary reference intake (DRI) for essential elements.

\begin{tabular}{l|cccccccc}
\hline \multicolumn{1}{c}{ Location } & $\begin{array}{c}\text { Lead } \\
(\mu \mathrm{g} / \text { day })\end{array}$ & $\begin{array}{c}\text { Arsenic } \\
(\mu \mathrm{g} / \text { day })\end{array}$ & $\begin{array}{c}\text { Chromium } \\
(\mu \mathrm{g} / \text { day })\end{array}$ & $\begin{array}{c}\text { Cadmium } \\
(\mu \mathrm{g} / \text { day })\end{array}$ & $\begin{array}{c}\text { Zinc } \\
(\mathrm{mg} / \mathrm{day})\end{array}$ & $\begin{array}{c}\text { Sodium } \\
(\mathrm{mg} / \mathrm{day})\end{array}$ & $\begin{array}{c}\text { Calcium } \\
(\mathrm{mg} / \mathrm{day})\end{array}$ & $\begin{array}{c}\text { Potassium } \\
(\mathrm{mg} / \mathrm{day})\end{array}$ \\
\hline Akure & 3.08 & 1.82 & 15.89 & 1.40 & 0.47 & 2.76 & 23.14 & 182.76 \\
Ondo & 3.36 & 2.17 & 21.56 & 1.19 & 0.42 & 3.37 & 24.05 & 183.81 \\
Ado-Ekiti & 2.87 & 3.01 & 45.36 & 1.05 & 0.48 & 2.66 & 23.64 & 184.99 \\
Igbemo & 3.43 & 4.13 & 57.61 & 1.82 & 0.62 & 3.01 & 23.09 & 186.38 \\
Ikole-Ekiti & 3.29 & 2.52 & 50.05 & 2.66 & 0.70 & 3.14 & 24.09 & 188.08 \\
Erinjiyan & 3.57 & 3.36 & 48.79 & 2.94 & 0.60 & 2.77 & 23.57 & 187.03 \\
Average EDI & 3.29 & 2.87 & 39.90 & 1.82 & 0.55 & 2.95 & 23.60 & 185.51 \\
PTDI/DRI & $35^{\mathrm{b}}$ & $150^{\mathrm{a}}$ & $35^{\mathrm{c}}$ & $70^{\mathrm{a}}$ & $8^{\mathrm{c}}$ & $1500^{\mathrm{c}}$ & $1200^{\mathrm{c}}$ & $4700^{\mathrm{c}}$ \\
\hline
\end{tabular}

Notes: ${ }^{\mathrm{a} P T D I}$, Provisional Tolerable Daily Intake for toxic elements based on PTWI/7 (WHO guidelines), ${ }^{\mathrm{b}}$ Corresponding benchmark dose lower confidence limit (BMDL) for lead were obtained by multiplying the BMDL value $0.5 \mu \mathrm{g} / \mathrm{kg} / \mathrm{day}$ (EFSA, 2010), ${ }^{\mathrm{c} D i e t a r y}$ reference intakes (DRIs) for essential elements are the most recent set of dietary recommendations established by the Food and Nutrition Board of the Institute of Medicine.

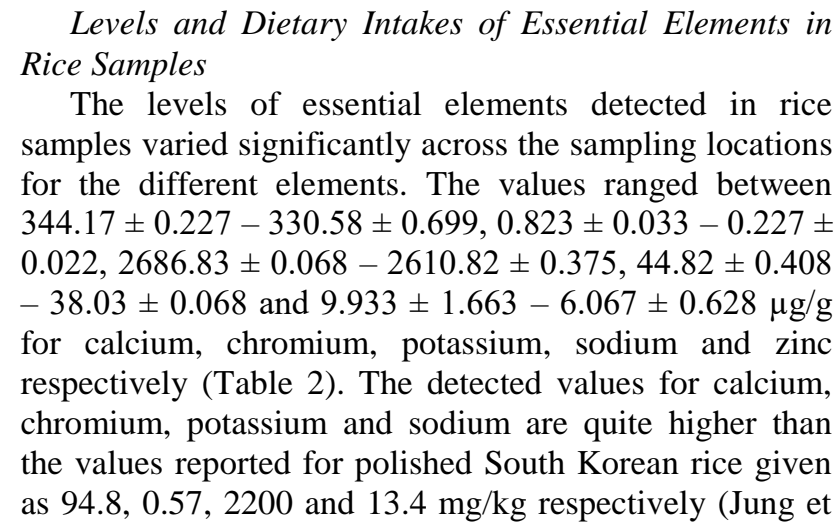

al., 2005). However, the detected values for zinc are quite low when compared to the values detected in South Korean rice samples reported as $17.0 \mathrm{mg} / \mathrm{kg}$ (Jung et al., 2005).

In humans, the essential elements play important roles in various biochemical and physiological activities; calcium is an essential component of bones and cartilage, and also play important role in blood clotting, by stimulating the release of thromboplastin from the blood platelets, enhance the action of insulin (Mertz, 1969), calcium deficiency can lead to rickets and poor blood clotting. Chromium plays significant role in the regulation of sugar levels in the body; its deficiency impairs the 
body's ability to utilize glucose to meet its energy needs and raises insulin requirements. Zinc interacts with a wide range of organic ligands and has roles in the metabolism of RNA and DNA. It also regulates apoptosis (Hambidge and Krebs, 2007). Sodium is essential for regulation of blood volume, blood pressure, osmotic equilibrium and pH (Geleijnse et al., 2004). Potassium is necessary for various physiological processes such as hormone secretion and action, vascular tone, systemic blood pressure control, gastrointestinal motility, acid-base balance, glucose and insulin metabolism (Linus and Wingo, 2013; Malnic et al., 2013). The deficiency of potassium in man could result in muscle weakness, paralytic decreased reflex response; and in severe cases, respiratory paralysis, alkalosis and cardiac arrhythmia (Visveswaran, 2009). Despite the usefulness of these elements in human, they are potentially harmful when their allowable levels in the body are exceeded. For example, a high level of chromium in the blood could result in damage to the blood cells through oxidation reactions which cause haemolysis, and subsequently kidney and liver failure (Dayan and Paine, 2001).

The estimated dietary intakes for the essential elements determined in this study are shown in Table 3. The estimated dietary intakes were $23.60 \mathrm{mg} /$ day, 39.90 $\mu \mathrm{g} /$ day, $185.51 \mathrm{mg} /$ day, $2.95 \mathrm{mg} /$ day and $0.55 \mathrm{mg} / \mathrm{day}$ for calcium, chromium, potassium, sodium and zinc respectively. These values were well below the dietary reference intake values for the elements except for chromium. The high dietary intake of chromium through consumption of local rice implies a serious health risk to human. The major source of contamination of rice with chromium is from the soil, so considerable attention should be given to remediation of soil's chromium level with a view to reducing the levels of chromium on Nigerian soils.

\section{Conclusion}

The findings of this study showed that the locally produced rice consumed in Ondo and Ekiti states of Nigeria contain low levels of toxic elements ( $\mathrm{Pb}, \mathrm{As}, \mathrm{Cd})$, and their estimated dietary intakes were well below the dietary reference intake values. However, the chromium levels detected in the rice samples is quite high, and this suggests the risk of chromium toxicity through rice consumption. On the other hand, the sampled rice in this study were not rich enough in sodium, calcium and potassium compared to the dietary reference intakes for these elements. It is recommended that rice diets should be supplemented with other food items such as meat, fruits and vegetables.

\section{Acknowledgements}

The authors are grateful to Mrs. Ojo of the Department of Biology, Federal University of Technology, Akure, Nigeria for assistance with laboratory analyses.

\section{References}

Adedire CO, Adeyemi JA, Paulelli AC, Martins-Junior AC, Ileke KD, Segura FR, de Oliveira-Souza VC, Batista BL, Barbosa Jr F. 2015. Toxic and essential elements in Nigerian rice and estimation of dietary intake through rice consumption. Food Additives and Contaminants Part B, 4: 271-276.

Ajijola S, Usman JM, Egbetokun OA, Akoun J, Osalusi CS. 2012. Appraisal of rice production in Nigeria: A case study of north central states of Nigeria. Journal of Stored Product and Postharvest Research, 3: 133 - 136.

AOAC. 2003. Official methods of analysis of the association of official's analytical chemists, $17^{\text {th }}$ edn. Association of Official Analytical Chemists, Arlington, Virginia.

APHA, WCPF. 1998. Standard methods for examination of water and wastewater. $20^{\text {th }}$ Edition. America Public Health Association, American Water Works and Water Control Pollution Federation, Washington DC, USA: 128.

Arsian S, Arikan A. 2013. Accumulation of heavy metals in bee products effects of distance from highway. Turkish Journal of Agriculture - Food Science and Technology, 1: 90-93.

Balkhair KS, Ashraf MA. 2016. Field accumulation risks of heavy metals in soil and vegetable crop irrigated with sewage water in western region of Saudi Arabia. Saudi Journal of Biological Sciences, 23: S32-S44.

Bamidele FS, Abayomi OO, Esther OA. 2010. Economic analysis of rice consumption patterns in Nigeria. Journal of Agricultural Science and Technology, 12: 1-11.

Batista BL, Nacano LR. Freitas R, Oliveira-Souza VC, Barbosa Jr F. 2012. Determination of essential (Ca, Fe, I, K, Mo) and toxic elements $(\mathrm{Hg}, \mathrm{Pb})$ in Brazilian rice grains and estimation of reference daily intake. Food and Nutrition Science, 3: 129-134.

Batista BL, Oliveira-Souza VC, Silva FG, Barbosa Jr F. 2010. Survey of 13 trace elements of toxic and nutritional significance in rice from Brazil and exposure assessment. Food Additives and Contaminants Part B, 3: 253-262.

Batista BL, Souza, JMO de Souza SS, Barbosa Jr F. 2011. Speciation of arsenic in rice and estimation of daily intake of different arsenic species by Brazilians through rice consumption. Journal of Hazardous Materials, 191: 342-348.

Dayan AD, Paine AJ. 2001. Mechanisms of chromium toxicity, carcinogenicity and allergenicity: Review of the literature from 1985 to 2000. Human and Experimental Toxicology, 20: 439451.

European Food Safety Authority. 2010. Scientific opinion on lead in food: EFSA panel on contaminants in the food chains. EFSA Journal, 8: 1570, $147 \mathrm{p}$.

Enterline PE, Day M, Marsh RG. 1995. Cancers related to exposure to arsenic at a copper smelter. Occupational and Environmental Medicine, 52: 28-32.

Food and Agricultural Organization (FAO). 2000. Agriculture towards 2015/30. Technical Interim Report. April, 2000. Rome.

Fu J, Zhou Q, Liu J, Liu W, Wang T, Zhang Q, Jiang G. 2008. High levels of heavy metals in rice (Oryza sativa L.) from typical Ewaste recycling area in southwest China and its potential risk to human health. Chemosphere, 71: 1269-1275.

Geleijnse JM, Kok FJ, Grobbee DE. 2004. Impact of dietary and lifestyle factors on the prevalence of hypertension in Western populations. European Journal of Public Health, 14: 235-239.

Hambidge KM, Krebs NF. 2007. Zinc deficiency: a special challenge. Journal of Nutrition, 137: 1101-1105.

Huang R, Gao S, Wang W, Staunton S, Wang G. 2006. Soil arsenic availability and the transfer of soil arsenic to crops in suburban areas in Fujian Province, southeast China. Science of the Total Environment, 368: 531-541.

Iloeje NP. 2001. A New Geography of Nigeria. Longman Nigeria Ltd, pp 200.

Institute of Medicine. 2004. Dietary reference intakes (DRIs): Recommended intakes for individuals (PDF), Food and Nutrition Board, National Academies, Washington (DC, USA). Retrieved 2009-06-09. 
Jung MC, Yun S, Lee J, Lee J. 2005. Baseline study on essential and trace elements in polished rice from South Korea. Environmental Geochemistry and Health, 27: 455-464.

Khush GS. 1997. Origin, dispersal, cultivation and variation of rice. Plant Molecular Biology, 35: 25-34.

Kurnaz A, Mutlu E, Aydın Uncumusaoğlu, A. 2016. Determination of Water Quality Parameters and Heavy Metal Content in Surface Water of Çiğdem Pond ( Kastamonu / Turkey). Turkish Journal of Agriculture - Food Science and Technology, 4 (10): 907- 913.

Linus S, Wingo CS. 2014. Disorders of potassium metabolism. In: Freehally J, Johnson RJ, Floege J. (eds). Comprehensive clinical nephrology, 5th ed, Saunders, St. Louis: pp 118.

Malnic G, Giebisch G, Muto S, Wang W, Bailey MA, Satlin LM. 2013. Regulation of $\mathrm{K}^{+}$excretion. In: Alpern RJ, Caplan MJ, Moe OW (eds). The kidney: physiology and pathophysiology, 5th ed, Academic Press, London, pp. 1659-1716.

Mertz W. 1969. Chromium occurrence and function in biological systems. Physiological Review, 49: 163-239.

Mudgal V, Maadan N, Mudgal A, Singh RB. 2010. Effect of toxic metals on human health. Open Nutraceuticals Journal, 3: 94-99.

Ossai EK, Iwegbue CM, Ajogungbe EA, Tesi GO. 2015. Polycyclic aromatic hydrocarbon and metal concentration in imported canned maize. Turkish Journal of Agriculture - Food Science and Technology, 3: 53-58.

Poletti J, Pozebon D, Fraga MVB, Dressler VL, Moraes DP. 2014 Toxic and micronutrient elements in organic, brown and polished rice in Brazil. Food Additives and Contaminants Part B, 7: 63-69.
Rastogi SK. 2008. Renal effects of environmental and occupational lead exposure. Indian Journal of Occupational and Environmental Medicine, 12: 103-106.

Satpathy D, Reddy MV, Dhal SP. 2014. Risk assessment of heavy metals contamination in paddy soil, plants, and grains (Oryza sativa $\mathrm{L}$.) at the east coast of India. BioMed Research International, 2014: 545473.

The Africa Rice Center. 2005. Rice trends in Sub-Saharan Africa. [cited 2015 Jul 27]. Available from: http://www.warda.cgiar.org/publications/Rice\%20Trends.pdf

Vavas-Acien A, Guallar E, Silbergeld EK, Rothenberg SJ. 2007. Lead exposure and cardiovascular disease - A systematic review. Environmental Health Perspectives, 115: 472-482.

Visveswaran K. 2009. Essentials of Nephrology, 2nd ed, BI Publications.

Williams PN, Price AH, Raab A, Hossain SA, Feldmann J, Meharg AA. 2005. Variation in arsenic speciation and concentration in paddy rice related to dietary exposure. Environmental Science Technology, 39: 5531-5540.

Yilmaz A, Yildiz S, Celik A, Cevik U. 2016. Determination of heavy metal and radioactivity in Agaricus campestris mushroom collected from Kahramanmaras and Erzurum proviencies. Turkish Journal of Agriculture- Food Science and Technology, 4: $208-215$.

Yoon KP. 2003. Construction and characterization of multiple heavy metal-resistant phenol-degrading pseudomonads strains. Journal of Microbiology and Biotechnology, 13: 1001-1007. 